\title{
POCHODNE INSTRUMENTY FINANSOWE NOTOWANE NA GIEŁDACH CHIŃSKIEJ REPUBLIKI LUDOWEJ
}

Chińska Republika Ludowa jest najdynamiczniej rozwijającym się krajem świata. Tendencja ta utrzymuje się już od ponad 30 lat i znacznie przewyższa dynamikę rozwoju krajów rozwiniętych. Motorem napędowym gospodarki jest produkcja oraz eksport wytworzonych produktów ${ }^{1}$. Powodem większej konkurencyjności chińskich produktów na innych rynkach są korzystne warunki dla przedsiębiorstw. Dużą rolę w sukcesie Chin odegrał także tzw. kult pracy, czyli wynikająca z tradycji pracowitość mieszkańców². Boom na giełdach jest spowodowany zainteresowaniem ich uczestników spółkami budowlanymi i spółkami nowych technologii ${ }^{3}$. Dodatkowym czynnikiem wpływającym na koniunkturę budowlaną była organizacja igrzysk olimpijskich w Pekinie w 2008 r., która wiązała się z ogromnymi inwestycjami budowlanymi ${ }^{4}$.

W artykule przedstawiono rynek pochodnych instrumentów finansowych (derywatów) na giełdach Chińskiej Republiki Ludowej. Omówiono główne giełdy instrumentów pochodnych oraz poddano analizie ofertę produktową na poszczególnych giełdach w latach 2016-2019. Teza badawcza opiera się na stwierdzeniu, że chiński rynek pochodnych instrumentów finansowych charakteryzuje się u progu trzeciej dekady XXI wieku bardzo dużą dynamiką rozwojowa, jednak w 2017 r. na skutek kryzysu finansowego na kilkanaście miesięcy nastąpiło wyhamowanie.

W artykule wykorzystano metodę badawczą opisową, dokumentacyjną oraz statystyczną.

1 Zob. szerzej: E. Oziewicz, Rola Chin we wspótczesnej globalnej gospodarce, „Gdańskie Studia Azji Wschodniej" 2015, z. 8, s. 144.

2 D. Cohen, China's GDP Growth Looks Set to Continue, „Business Week”, 12.10.2006, s. 4.

3 Por. K. Żukrowska, Chiny: potencjał (gospodarczyy, polityczny, militarny) jako instrument ksztattowania nowego układu międsynnarodowego, „Krakowskie Studia Międzynarodowe” 2018, nr 1 (XV), s. 34.

4 E. Cieślik, Efekt Smoka. Skutki ekspansji gospodarczej Chin po 1978 roku, Warszawa 2012, s. 82. 


\section{Charakterystyka giełd w Chińskiej Republice Ludowej}

Chiny odgrywają coraz istotniejszą rolę w kształtowaniu się globalnych rynków finansowych. Rozwój ekonomiczny kraju poprzez zbudowanie silnej realnej gospodarki i w efekcie zwiększającego się potencjału giełdowego zaplecza finansowego oraz inwestycyjnego stwarza nowe możliwości.

Chiński rynek akcji i obligacji nieustannie się rozwija i pod względem wielkości zajmuje drugie miejsce na świecie (wyprzedza go tylko rynek amerykański) Jego udział zagraniczny wciąż wzrasta, próbując dorównać wysoko rozwiniętym gospodarkom. W ChRL funkcjonują trzy tradycyjne giełdy specjalizujące się w notowaniach akcji i obligacji. Sa to Shanghai Stock Exchange (SSE), Shenzhen Stock Exchange (SZSE) oraz Hong Kong Stock Exchange (HKSE). Wszystkie one w XXI wieku rozwijały się w bardzo szybkim tempie, oferując swoim klientom wszechstronną obsługę w obrocie akcjami i obligacjami. Dzięki efektywnemu systemowi samoregulacji oraz rozbudowanej technologicznie i nowoczesnej infrastrukturze komunikacyjnej zapewniają najwyższe standardy obsługi oraz przyciagają wielu inwestorów zarówno krajowych, jak i zagranicznych. Pod względem kapitalizacji Shanghai Stock Exchange zajmuje czwarte miejsce na świecie (drugie w Azji - po Japan Exchange Group Inc.), Hong Kong Stock Exchange - siódme, zaś Shenzhen Stock Exchange - ósmé .

$\mathrm{Na}$ Shanghai Stock Exchange notowana jest szeroka gama akcji i obligacji. Z roku na rok powiększa się oferta dostępnych produktów giełdowych. Na początku stycznia 2020 r. były tu notowane akcje 1626 spółek, których obrót wyniósł 328 mld CNY. Całkowita liczba notowanych papierów wartościowych wynosiła $15186^{7}$.

Na początku stycznia 2020 r. na Shenzhen Stock Exchange notowane były akcje 2314 spółek. W ofercie występowało 8738 produktów, do których należą instrumenty finansowe $z$ kategorii akcji, obligacji, funduszy inwestycyjnych oraz papierów wartościowych zabezpieczanych aktywami ${ }^{8}$. Głównym indeksem występujacym na Shenzhen Stock Exchange jest SZSE Component, będący indeksem akcji 40 największych spółek. Dynamiczny postęp technologiczny regionu i całego kraju sprawił, że na giełdzie w Shenzhen są notowane przede wszystkim spółki nowych

5 E. Cerutti, M. Obstfeld, China's Bond Market and Global Financial Markets, IMF Working Paper, International Monetary Fund 2018, s. 4.

6 World Federation of Exchanges, https://focus.world-exchanges.org/issue/may-2019/market-statistics (dostęp: 27.01.2020).

7 Shanghai Stock Exchange, www.english2019.sse.com.cn (dostęp: 25.01.2020).

8 Shenzhen Stock Exchange, http://www.szse.cn/English/about/overview/index.html (dostęp: 27.01.2020). 
technologii9. SZSE nie skupia tylko i wyłącznie dużych podmiotów, ale też mniejsze $\mathrm{i}$ innowacyjne przedsiębiorstwa. Specjalnie dla nich został stworzony osobny parkiet giełdowy zrzeszający nowatorskie spółki i startupy ${ }^{10}$.

Z kolei dynamiczne zmiany zachodzące na Hong Kong Stock Exchange w latach 2016-2019 zaowocowały wzrostem liczby notowanych spółek. W 2016 r. liczba przedsiębiorstw wynosiła 1973, natomiast na koniec 2019 r. wzrosła do 2323. Duże zainteresowanie spółek debiutem giełdowym na HKEX nie maleje. Co roku przybywa około stu nowych podmiotów. Dynamiczny rozwój ma odzwierciedlenie we wzroście kapitalizacji rynkowej ${ }^{11}$.

Należy jednak podkreślić, że analizowane wyżej giełdy w niewielkim stopniu specjalizuja się w notowaniach pochodnych instrumentów finansowych. W Chińskiej Republice Ludowej pięć giełd zajmuje się notowaniami pochodnych instrumentów finansowych. Każda z nich ma swoją specyfikę i wypełnia określoną niszę na rynku. Wszystkie znajdują się w grupie światowych liderów w ramach swojej specjalizacji. Jednak wysoka pozycję w rankingach giełd zajęły one dopiero w drugiej dekadzie XXI wieku. Jeszcze przed 2010 r. gama oferowanych instrumentów pochodnych była skromna, zaś zainteresowanie nimi - niewielkie. Po kryzysie finansowym w 2017 r., kiedy obroty i wolumen spadły, w 2019 r. wszystkie giełdy odnotowują bardzo dynamiczny wzrost obrotów i wolumenu. O ile jeszcze w 2015 r. giełdy oferowały wyłącznie kontrakty futures, o tyle na początku 2020 r. każda z giełd ma w ofercie również kontrakty opcyjne. Nie cieszą się one jeszcze dużym zainteresowaniem inwestorów, jednak można sądzić, że w latach 2020-2023 będą stawały się coraz bardziej popularne.

W zakresie specjalizacji należy podkreślić, że SSE jest tradycyjna giełdą papierów wartościowych, na której notowane są też nieliczne opcje na akcje. SSE nie ma w ofercie towarowych instrumentów pochodnych. Walory te są z kolei jedynymi dostępnymi na trzech kolejnych giełdach: Shanghai Futures Exchange (SHFE), Dalian Commodity Exchange (DCE) i Zhengzhou Commodity Exchange (ZCE). Należy również wskazać, że wszystkie wyżej omówione giełdy (za wyjątkiem HKEX) utworzyły wspólną platformę - giełdę China Financial Futures Exchange (CFFEX), na której notowane są kontrakty futures na indeksy akcji (kategoria instrumentów pochodnych rynku kapitałowego) oraz kontrakty futures na obligacje (kategoria procentowych instrumentów pochodnych). Do 2017 r. dominująca grupą były kontrakty futures na obligacje, zaś od 2018 r. największym zainteresowaniem cieszą się pochodne indeksowe. Od 2019 r. oferowane są opcje indeksowe, które nie sa jeszcze zbyt często wykorzystywane.

\footnotetext{
9 J. Strzelecki, Giełda po chinskeu, „Gazeta Bankowa” 2015, nr 10, s. 58; I. Kujawa, Shenzhen miasto z. chińskich snów, „Anthropos? Miasto i Miejsce” 2015, nr 24, s. 135.

10 M. Markiewicz, U. Mrzygłód, Finanse miedzynarodowe: nybrane problemy, Warszawa 2015, s. 175.

11 Hongkong Stock Exchange and Clearing: https://www.hkexgroup.com/About-HKEX/ Company-Information/ (dostęp: 27.01.2020).
} 


\section{Istota pochodnych instrumentów finansowych}

Pochodne instrumenty finansowe (derywaty, ang. derivatives) są to instrumenty finansowe, których cena jest zależna od ceny innych instrumentów określanych jako instrumenty podstawowe (bazowe, pierwotne) ${ }^{12}$.

Ze względu na rodzaj instrumentu bazowego możemy wyróżnić:

- instrumenty pochodne rynku kapitałowego, których cena jest zależna od wartości indeksów akcji lub od kursów akcji pojedynczych spółek (np. kontrakty futures na indeks WIG20, kontrakty futures na kurs akcji spółki Polski Koncern Naftowy Orlen, opcje na indeks WIG20),

- procentowe instrumenty pochodne, których cena zależy od cen obligacji lub stóp procentowych (np. kontrakty futures na obligacje skarbowe, kontrakty futures na stopę procentową LIBOR),

- walutowe instrumenty pochodne opierające się na kursach walutowych (np. kontrakty futures na kurs USD/PLN, na kurs EUR/USD),

- towarowe instrumenty pochodne, których cena zależy od cen towarów (np. kontrakty furures na energię elektryczną, kontrakty futures na półtusze wieprzowe).

Rosnąca popularność derywatów oraz rozwój rynków finansowych sprzyjaja powstawaniu gamy nowej i innowacyjnej oferty. Do takiej należy zaliczyć funkcjonujące na rynku pochodne instrumenty kredytowe, których poziom ceny waha się w zależności od ratingu kredytowego. Dostępne są również derywaty pogodowe, bazujące na zmianach warunków atmosferycznych.

Należy też wspomnieć o podziale giełdowych pochodnych instrumentów finansowych na kontrakty futures (kontrakty terminowe) oraz na opcje (kontrakty opcyjne). Kontrakty futures nie wymagaja w chwili rozpoczęcia inwestycji zapłaty (poza niewielką prowizją maklerską i kaucją określaną mianem depozytu zabezpieczającego), przy czym o ile w sytuacji, gdy inwestor prawidłowo przewidzi zmiany kursów instrumentu bazowego, wówczas odnotowuje znaczący zysk, o tyle w przypadku przeciwnego wobec przewidywań inwestora zachowania kursów - uczestnik rynku poniesie stratę.

Z kolei kontrakty opcyjne w momencie rozpoczęcia inwestycji wymagają wpłaty bezzwrotnej premii opcyjnej (poza prowizja maklerska i depozytem zabezpieczającym). W chwili zakończenia inwestycji inwestor, który prawidłowo przewidział zmiany kursów instrumentu finansowego, odnotowuje znaczący zysk (pomniejszony w stosunku do kontraktów futures o wysokość premii), zaś w przypadku przeciwnego wobec przewidywań inwestora zachowania kursów - uczestnik kończy inwestycję z wynikiem zero.

12 S. Antkiewicz, Papiery wartościowe na rynku pienieżnym i kapitałowym, Warszawa 2012, s. 229. 
Opcje jako bardziej skomplikowany instrument są rzadziej notowane na giełdach. Natomiast kontrakty futures są dostępne niemal na każdej giełdzie świata, która prowadzi notowania instrumentów pochodnych.

\section{Shanghai Stock Exchange (SSE) - główny rynek giełdowy w Chinach}

Szanghaj jest największym miastem w Chińskiej Republice Ludowej, a jego powierzchnia wynosi prawie 7 tys. $\mathrm{km}^{2} \mathrm{z}$ liczbą mieszkańców ponad $25 \mathrm{mln}^{13}$. Shanghai Stock Exchange została założona 26 listopada $1990 r .{ }^{14} \mathrm{~W}$ ciagu kilkunastu lat funkcjonowania stała się największą giełdą w ChRL. Dominuje we wszystkich segmentach, tj. w liczbie notowanych spółek, w liczbie uczestników, w wartościach obrotów akcjami, obligacjami oraz pochodnymi instrumentami finansowymi (opcjami). Przykładowo w grudniu 2006 r. na giełdzie notowane były akcje 837 spółek, a w transakcjach brało udział $37,87 \mathrm{mln}$ inwestorów ${ }^{15}$. W $2006 \mathrm{r}$. kapitalizacja giełdy wyniosła 45,7 mld CNY ${ }^{16}$. Natomiast w styczniu $2020 \mathrm{r}$. na giełdzie notowane były akcje 1626 spółek, a kapitalizacja wyniosła 691,3 mld CNY. Wysokie obroty wynikają głównie z liczby spółek oraz z przedmiotu ich działalności. Na SSE notowana jest duża liczba spółek z sektora przemysłowego, budowlanego oraz nowoczesnych technologii, które cieszą się ogromnym zainteresowaniem inwestorów z powodu trwającego boomu budowlanego i technologicznego. SSE jest uczestnikiem Światowej Federacji Giełd (WFE), Międzynarodowej Organizacji Komisji Papierów Wartościowych (IOSCO) oraz Federacji Papierów Wartościowych Azji i Oceanii (AOSEF). Giełda w Szanghaju współpracuje z giełdami na całym świecie, m.in. $z$ London Stock Exchange (LSE), Hong Kong Exchanges and Clearing Limited (HKEx), Bolsa de Valores, Mercadorias and Futuros (BOVESPA Sao Paulo), Tokyo Stock Exchange (TSE), New York Stock Exchange (NYSE), Moscow Exchange (MoEx, wcześniej MICEX), Oslo Bors (OB). Na SSE notowane są akcje, obligacje skarbu państwa, obligacje przedsiębiorstw, fundusze, a spośród pochodnych instrumentów finansowych: opcje kupna i sprzedaży.

Z roku na rok powiększa się oferta notowanych instrumentów giełdowych, a ich charakterystyka została przedstawiona w tabeli 1 . Według stanu na 24 stycznia 2020 r. na SSE były notowane akcje 1626 spółek, a obrót nimi wyniósł 328 mld CNY.

13 Por. E. Cieślik, Roẓvój gospodarçyy Chin od roku 1978 do kryzysu globalnego, Warszawa 2015, s. 13.

14 Shanghai Stock Exchange, www.sse.com.cn (dostęp: 27.01.2020); por. też: S.M.L. Wong, China's Stock Market: A Marriage of Capitalism and Socialism, „Cato Jurnal” 2006, vol. 26, s. 18.

15 F. Lincheng, X. Weihe, Has the Reform of Nontradable Shares Raised Prices?, „Emerging Markets Finance \& Trade" 2007, nr 5/6, s. 34.

16 W. Tan, Breathing Life Into Insurance, „Beijing Review”, 25.01.2007, s. 37. 
Liczba dostępnych funduszy osiagnęła wartość 318, a ich wartość 39 mld CNY. Dzienny wolumen opcji wyniósł 2023 018, zaś liczba otwartych pozycji osiagnęła wartość 1287459 .

Tabela 1. Charakterystyka instrumentów na SSE (stan na 24.01.2020 r.)

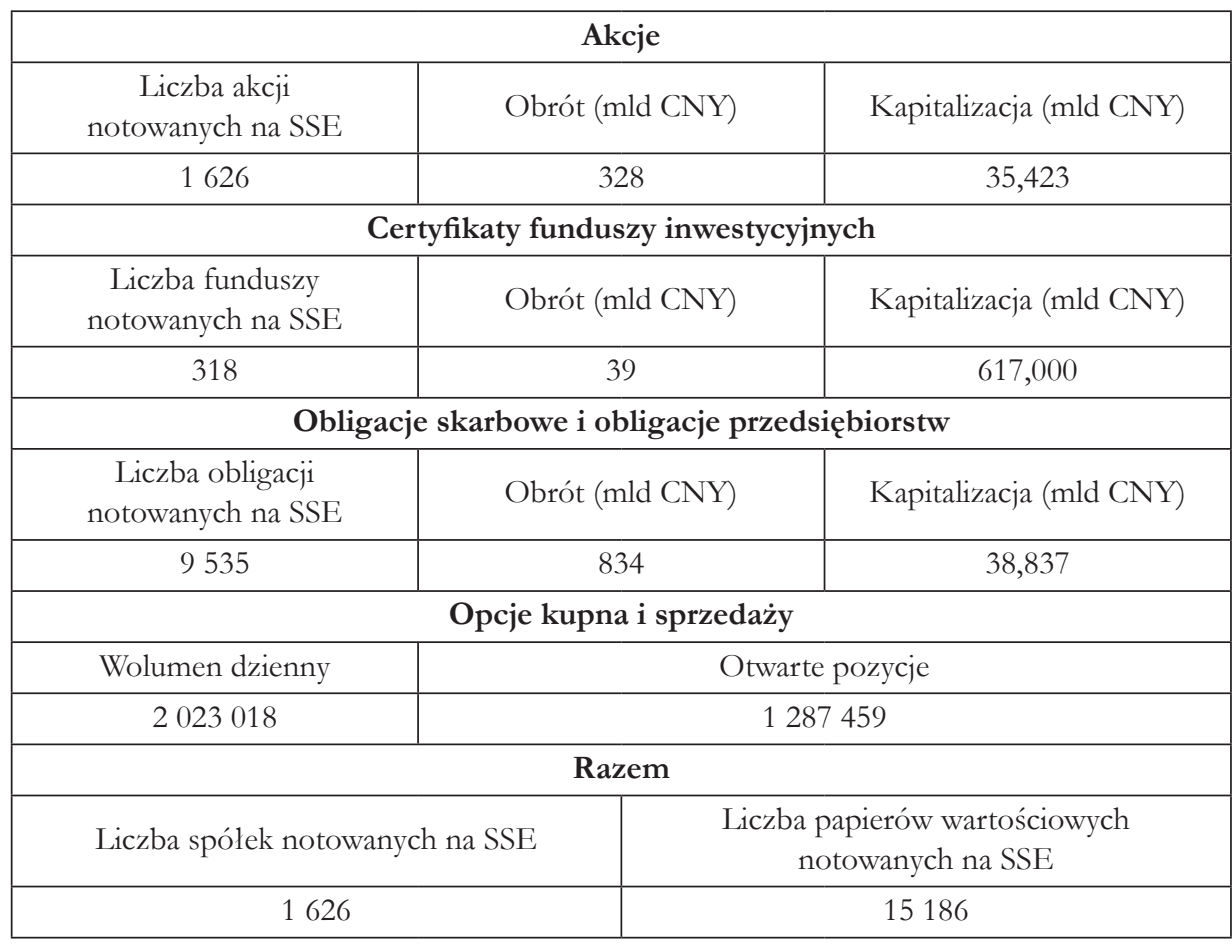

Źródło: Opracowanie własne na podstawie danych Shanghai Stock Exchange, www.english2019.sse. com.cn (dostęp: 25.01.2020).

Akcje dopuszczone do obrotu dzielą się na akcje typu A, denominowane w walucie krajowej (CNY), przeznaczone dla krajowych instytucji, przedsiębiorstw i osób fizycznych oraz akcje typu B - specjalne, subskrybowane i handlowane w dolarze amerykańskim (USD), przeznaczone dla podmiotów zagranicznych ${ }^{17}$. Ponadto notowane są certyfikaty funduszy zamkniętych, innowacyjnych funduszy zamkniętych, funduszy giełdowego rynku pieniężnego, funduszy Exchange Traded Funds. Do obrotu dopuszczono również obligacje skarbowe i obligacje korporacyjne. Spośród instrumentów pochodnych dostępne są opcje kupna i opcje sprzedaży. Na Shanghai Stock Exchange nie sa notowane kontrakty terminowe futures.

17 S.N. Neftci, M. Yuan Ménager-Xu, China's Financial Markets: An Insider's Guide to How the Markets Work, Burlington, MA-San Diego-London 2007, s. 8. 


\section{Instrumenty pochodne notowane na Shanghai Futures Exchange}

Shanghai Futures Exchange powstała w grudniu 1999 r. w Szanghaju w wyniku połączenia kilku mniejszych giełd futures, tj. Shanghai Metal Exchange (SHME), Shanghai Cereals and Oil Exchange (SHCOE) oraz Shanghai Commodity Exchange (SHCE) ${ }^{18}$. Podlega ścisłej i jednolitej regulacji Chińskiej Komisji Regulacyjnej ds. Papierów Wartościowych (CSRC). W związku z prawem obowiązującym w ChRL uczestnikami tej giełdy moga zostać jedynie te podmioty, które mają siedzibę w Chinach.

Shanghai Futures Exchange jest największą giełdą towarową w państwie. Współpracuje z największymi giełdami towarowymi na świecie, np. z London Metal Exchange (LME) oraz z New York Mercantile Exchange (NYMEX).

Na początku swojej działalności oferowała kontrakty na miedź, aluminium i kauczuk naturalny. Głównym celem SHFE było zaopatrzenie rynku chińskiego w surowce. Na dzień 24 stycznia 2020 r. SHFE miała w ofercie osiemnaście kontraktów futures. Można je podzielić na trzy kategorie: kontrakty na metale (miedź, aluminium, cynk, lit, ołów, nikiel, cyna, złoto, srebro, pręty zbrojeniowe stalowe, pręty walcowane na gorąco, walcowane zwoje, cewki klasyczne, walcowane cewki), kontrakty na surowce energetyczne (ropa naftowa, olej opałowy, bitum), kontrakty na kauczuk naturalny. Ponadto przedmiotem obrotu są również opcje kupna i sprzedaży na miedź, złoto i kauczuk naturalny ${ }^{19}$.

W tabeli 2 przedstawiono obroty oraz wolumen kontraktów futures na Shanghai Futures Exchange w latach 2016-2019. Obroty kontraktami w 2016 r. zwiększyły się o 33,71\% w stosunku do roku poprzedniego. Na przełomie 2016 i 2017 r. nastąpiła zmiana trendów. Jak wynika z prezentowanych danych, w latach 2017-2018 na skutek kryzysu finansowego dynamika wzrostu obrotów i wolumen spadły. Jednak w 2019 r. zarówno obroty, jak i wolumen wróciły na dynamiczną ścieżkę wzrostowa. Bardzo duże zainteresowanie kontraktami wynikało z szerokiego wykorzystania surowców notowanych na SHFE przez rodzime przedsiębiorstwa.

W pierwszym kwartale 2018 r. na Shanghai Futures Exchange zadebiutowały notowania opcji na miedź. Z kolei w 2019 r. wprowadzono opcje na złoto i kauczuk naturalny. Wartość obrotów i wolumen opcji na SHFE przedstawiono w tabeli 3.

18 X. Lan, Let's Buy Futures, „Beijing Review”, 21.06.2007, s. 34; H.G. Fung, Q. Wilson-Liu, Y. Tse, The information flow and market efficiency between the U.S. and Chinese aluminum and copper futures markets, „Journal of Futures Markets” 2010, vol. 30, s. 15; M. Chylińska, P. Miłobędzki, Zależności mięży cenami kontraktów terminowych na mied乏́, na Giełdzie Kontraktów Terminonych w Szanghaju, „Zarządzanie i Finanse" 2015, nr 4/2, s. 5.

19 Shanghai Futures Exchange, www.shfe.com.cn/en (dostęp: 27.01.2020). 
Tabela 2. Wartość obrotów i wolumen kontraktów futures na SHFE w latach 2016-2019

\begin{tabular}{|c|c|c|c|c|}
\hline Rok & Obroty (mld CNY) & Zmiana w \% & Wolumen & Zmiana w \% \\
\hline 2016 & 169954,982 & 33,71 & 3361423682 & 59,99 \\
\hline 2017 & 179862,069 & 5,83 & 2728487056 & $-18,83$ \\
\hline 2018 & 188544,333 & 4,83 & 2401411652 & $-11,99$ \\
\hline 2019 & 225018,771 & 19,35 & 2885073164 & 20,14 \\
\hline
\end{tabular}

Źródło: Opracowanie własne na podstawie danych z: http://www.shfe.com.cn/en/MarketData/ (dostęp: 25.01.2020).

Tabela 3. Wartość obrotów i wolumen opcji na SHFE w latach 2018-2019

\begin{tabular}{|l|l|r|r|c|}
\hline \multicolumn{2}{|c|}{ Opcja na SHFE } & \multicolumn{1}{c|}{ 2018 } & \multicolumn{1}{c|}{$\mathbf{2 0 1 9}$} & Zmiana w \% \\
\hline \multirow{2}{*}{$\begin{array}{l}\text { Opcja } \\
\text { na miedź }\end{array}$} & obroty (mln CNY) & 17722,46 & 22709,71 & 28,14 \\
\cline { 2 - 5 } & wolumen & 2526360,00 & 8394966,00 & 232,29 \\
\hline \multirow{2}{*}{$\begin{array}{l}\text { Opcja } \\
\text { na złoto }\end{array}$} & obroty & 0 & 640,63 & - \\
\cline { 2 - 5 } & wolumen & 0 & 81852,00 & - \\
\hline $\begin{array}{l}\text { Opcja } \\
\text { na kauczuk } \\
\text { naturalny }\end{array}$ & obroty & 0 & 4476,31 & - \\
\cline { 2 - 5 } & wolumen & 0 & 1644126,00 & - \\
\hline
\end{tabular}

Źródło: Opracowanie własne na podstawie danych z: http://www.shfe.com.cn/en/MarketData/ (dostęp: 27.01.2020).

Na koniec 2019 r. obroty i wolumen na opcjach na miedź stanowił około 82\% udziału w łącznych obrotach i wolumenie na opcjach. Kontrakty opcyjnie na miedź charakteryzują się wysoką dynamiką wzrostu rynku. Kontrakty opcyjnie na kauczuk charakteryzowały się około szesnastoprocentowym udziałem w łącznych obrotach i wolumenie. Należy sądzić, że w latach 2020-2021 udział ten istotnie wzrośnie. Zainteresowanie inwestorów opcjami na złoto jest marginalne.

\section{Dalian Commodity Exchange}

Dalian Commodity Exchange powstała 28 lutego 1993 r. ${ }^{20}$ Siedziba giełdy znajduje się w północno-wschodnich Chinach, w mieście Dalian. Giełda bardzo szybko się rozwijała. Za cel postawiła sobie zostanie centrum światowego obrotu towarami nie tylko rolniczymi, ale także niezwiązanymi z rolnictwem. DCE jest członkiem amerykańskiej giełdy Futures Industry Association oraz angielskiej Futures and Options Association. Ponadto współpracuje z wieloma giełdami na

${ }^{20}$ Dalian Commodity Exchange, www.dce.com.cn (dostęp: 27.01.2020). 
całym świecie, np. z Chicago Mercantile Exchange (CME), Chicago Board of Trade (CBOT), Chicago Board Options Exchange (CBOE), Tokyo Commodity Exchange (TOCOM).

Stanowi jedną z największych giełd towarowych w Chinach. Na początku działalności specjalizowała się w artykułach rolnych, zwłaszcza soi. Jednak od 2015 r. rośnie ranga dwóch nowych segmentów rynkowych: metalurgicznego oraz petrochemicznego ${ }^{21}$.

Giełda w Dalian zajmuje drugie miejsce na świecie pod względem kontraktów futures na kukurydzę ${ }^{22}$. Głównym celem wykorzystania kontraktów notowanych na DCE jest zabezpieczenie przed zmianami cen plonów rolnych. DCE ma pozwolenie na wprowadzenie derywatów pogodowych, planuje wdrożyć instrumenty pochodne na temperaturę, opady deszczu, śniegu, huragany oraz wilgotność. Rozszerzenie oferty produktowej o derywaty pogodowe ma na celu zwiększenie zainteresowania giełda przez inwestorów.

Pełna lista dostępnych derywatów w styczniu 2020 r. zawierała 19 kontraktów futures bazujących na: fasoli sojowej No. 1, fasoli sojowej No. 2, płytach technicznych, kukurydzy, skrobi kukurydzianej, etylinie, glikolu, płycie pilśniowej, rudzie żelaza, koksie, jajach, węglu koksującym, polietylenie LLDPE, mące sojowej, oleju palmowym, polipropylenie, ryżu, polichrolku winylu PVC, oleju sojowym. Ponadto w styczniu 2020 r. notowane były również opcje na ryż, mąkę sojową i rudę żelaza ${ }^{23}$.

Wartość wolumenu i obrotów kontraktami futures, które były notowane w latach 2016-2019 na Dalian Commodity Exchange, zaprezentowano w tabeli 4. W omawianym okresie zaszły dynamiczne zmiany. W 2016 r. kontrakty futures na DCE cieszyły się dużym zainteresowaniem ze strony inwestorów. Obroty zwiększyły się o 46,43\% w stosunku do roku poprzedniego i wynosiły 61 405,30 mld CNY. Wolumen wzrósł o 37,73\% (do 1537479768 sztuk). W roku 2017 odnotowano dynamiczny spadek obrotów $(-15,31 \%)$ i wolumenu $(-28,61 \%)$, a w 2018 odnotowano stagnację. Jednak w 2019 r. można zaobserwować istotny wzrost zainteresowania inwestorów (obroty wzrosły o 32,06\%, zaś wolumen o 37,26\%).

W tabeli 5 zaprezentowano dane dotyczące rynku opcji na ryż, mąkę sojowa oraz rudę żelaza w latach 2017-2019 na Dalian Commodity Exchange. Wszystkie wartości zwiększyły się.

${ }^{21} \mathrm{~J}$. Tomaszewski, Rozwój rynku terminowego na giełdach towaronych w Chinach i jego powiazania z.globalnym rynkiem terminowym - analiza rynku kontraktów futures na metale przemystowe i szlachetne, „Finanse, Rynki Finansowe, Ubezpieczenia” 2017, nr 1, s. 558, 559.

22 M. Trombly, W. Yu, China, Japan, Futures Market Cooperate on Weather Derivatives, „Securities Industry News", 10.07.2006, s. 10.

${ }^{23}$ Dalian Commodity Exchange, http://www.dce.com.cn/DCE/Products/Agriculture (dostęp: 27.01.2020). 
Tabela 4. Wartość obrotów i wolumen kontraktów futures na DCE w latach 2016-2019

\begin{tabular}{|c|c|c|c|c|}
\hline Rok & $\begin{array}{c}\text { Obroty } \\
\text { (mld CNY) }\end{array}$ & Zmiana w \% & Wolumen & Zmiana w \% \\
\hline 2016 & 61405,30 & 46,43 & 1537479768 & 37,73 \\
\hline 2017 & 52004,67 & $-15,31$ & 1097644470 & $-28,61$ \\
\hline 2018 & 52186,40 & 0,35 & 969405778 & $-11,68$ \\
\hline 2019 & 68915,46 & 32,06 & 1330650938 & 37,26 \\
\hline
\end{tabular}

Źródło: Opracowanie własne na podstawie danych Dalian Commodity Exchange, http://www.dce. com.cn/DCE/Market_Data/Market (dostęp: 27.01.2020).

Tabela 5. Wartość obrotów i wolumen opcji na DCE w latach 2017-2019

\begin{tabular}{|l|c|c|c|c|c|c|}
\hline \multicolumn{1}{|c|}{ Opcje } & $\mathbf{2 0 1 7}$ & $\begin{array}{c}\text { Zmiana } \\
\mathbf{w} \%\end{array}$ & $\mathbf{2 0 1 8}$ & $\begin{array}{c}\text { Zmiana } \\
\mathbf{w} \%\end{array}$ & $\mathbf{2 0 1 9}$ & $\begin{array}{c}\text { Zmiana } \\
\mathbf{w} \%\end{array}$ \\
\hline $\begin{array}{l}\text { Obroty } \\
\text { (mld CNY) }\end{array}$ & 2,39 & $\begin{array}{c}\text { brak } \\
\text { odniesienia }\end{array}$ & 9,27 & 287,95 & 9,86 & 6,41 \\
\hline Wolumen & 3635682,00 & $\begin{array}{c}\text { brak } \\
\text { odniesienia }\end{array}$ & 12521591,00 & 287,95 & 24933287,00 & 99,12 \\
\hline
\end{tabular}

Źródło: Dalian Commodity Exchange, http://www.dce.com.cn/DCE/Market_Data/Market (dostęp: 27.01.2020).

\section{Zhengzhou Commodity Exchange}

Zhengzhou Commodity Exchange powstała 12 października 1990 r. we wschodnich Chinach, w mieście Zhengzhou. Na giełdzie tej notowane sa kontrakty futures wystawione na produkty rolnicze, produkty przemysłowe, energię oraz materiały nieprzetworzone. Pierwsze kontrakty futures pojawiły się na ZCE 28 maja 1993 r. ${ }^{24}$

ZCE była zatem pierwszym rynkiem kontraktów terminowych futures w Chinach. Do 2006 r. w swojej ofercie miała tylko produkty rolnicze. Wraz z rozwojem specyfiki prowincji, w której się znajduje, ZCE całkowicie zmieniła strukturę produktowa, która od tej pory skupiała się na dwóch głównych źródłach obrotu: petrochemicznych towarach przetworzonych oraz towarach rolniczych ${ }^{25}$. Transformacja przemysłowa regionu wpłynęła na nowe strategie stosowane przez inwestorów. W 2013 r. udział towarów przetworzonych $\mathrm{w}$ wolumenie obrotów pierwszy raz przewyższył połowę, jedną czwartą stanowił wolumen obrotu kontraktami terminowymi na zboża, a tak-

${ }^{24}$ L.H. Chan, K.C. Chan, W.K. Leung, Institutional Interventions and Performance of Futures Markets in China, „Emerging Market Finance \& Trade” 2005, no. 5, s. 46.

25 Zhengzhou Commodity Exchange, http://english.czce.com.cn/enportal/AboutZCE/ Overview/Overview/H69010101index_1.htm (dostęp: 27.01.2020). 
że niespełna jedną czwarta - na pozostałe kontrakty futures. W dużej mierze wzrost ten nastapił w wyniku ogromnego zainteresowania kontraktami futures na bawełnę ${ }^{26}$. W 2018 r. średnia dzienna liczba kontraktów na ZCE zawierała się w przedziale od 60 tys. do 80 tys., podobnie jak na New York Cotton Exchange. Warto dodać, że nowojorska giełda ma ponad 130-letnią tradycję, a ZCE jest relatywnie młoda.

Oferowane kontrakty futures opieraja się na produktach pochodzacych z najważniejszych gałęzi gospodarki państwowej. Z produktów rolniczych wyróżniamy futures na: pszenicę WH, pszenicę PM, bawełnę No. 1, biały cukier, olej rzepakowy, wczesny ryż, ryż japonica, rzepak, mączkę rzepakową, późny ryż indica, przędzę bawełniana, jabłka i chińska jujubę ${ }^{27}$. Z grupy produktów nierolniczych notowane są natomiast futures na: kwas PTA, szkło, koks energetyczny, metanol, żelazokrzem, mocznik i sodę kalcynowana.

W tabeli 6 przedstawiono wartość oraz wolumen obrotów kontraktami futures notowanych na Zhengzhou Commodity Exchange w latach 2016-2017. Jak wynika z zaprezentowanych danych, w 2017 r. zainteresowanie inwestorów zmniejszyło się i nie wykazywali chęci zakupu oferowanych instrumentów pochodnych. Wolumen spadł o 31,15\%. Na koniec 2017 r. wyniósł 1169155 510. Ograniczona liczba kupowanych kontraktów futures miała swoje odzwierciedlenie w obrotach, które spadły w 2017 r. o 35,14\% i wyniosły 42,73 mld CNY. Jednak w przeciwieństwie do innych giełd, na których w 2018 r. można było jeszcze zaobserwować stagnację, na Zhengzhou Commodity Exchange rok 2018 charakteryzował się już znaczącymi wzrostami obrotów i wolumenu. Na koniec listopada 2019 r. zarówno obroty, jak i wolumen były znacząco wyższe niż na koniec 2016 r., czyli w okresie poprzedzającym kryzys finansowy.

Ponadto od 2018 r. notowane były również opcje na biały cukier, zaś od 2019 r. na kwas PTA, metanol i mączkę rzepakową.

Tabela 6. Wartość obrotów i wolumen kontraktów futures na ZCE w latach 2016-2019

\begin{tabular}{|c|c|c|c|c|}
\hline Rok & $\begin{array}{c}\text { Obroty } \\
\text { (mld CNY) }\end{array}$ & Zmiana w \% & Wolumen & Zmiana w \% \\
\hline 2016 & 62064,99 & $\cdot$ & 1802594094 & $\cdot$ \\
\hline 2017 & 42734,30 & $-35,14$ & 1097644470 & $-31,15$ \\
\hline 2018 & 76450,57 & 78,90 & 1626753174 & 39,14 \\
\hline $01-11.2019$ & 73348,06 & 3,26 & 2000122658 & 36,13 \\
\hline
\end{tabular}

Źródło: Zhengzhou Commodity Exchange, http://english.czce.com.cn/enportal/MarketData/Futures/DailyTradingData (dostęp: 27.01.2020).

${ }^{26}$ F. Laws, Exceeds NYBOT volume China's cotton futures trading heavy, „Southeast Farm Press”, 15.06.2005, s. 25.

27 Zhengzhou Commodity Exchange, http://english.czce.com.cn/enportal/Products/Agriculture/Wheat (dostęp: 27.01.2020). 


\section{China Financial Futures Exchange jako rynek finansowych instrumentów pochodnych}

China Financial Futures Exchange (CFFEX) została założona wspólnie przez Shanghai Futures Exchange, Zhengzhou Commodity Exchange, Dalian Commodity Exchange, Shanghai Stock Exchange i Shenzhen Stock Exchange we wrześniu 2006 r. Głównym powodem jej założenia była potrzeba stworzenia miejsca obrotu i rozliczania finansowych kontraktów futures, opcji i pozostałych instrumentów pochodnych $^{28}$.

Swoją działalnością giełda wspiera budowanie wieloelementowego rynku kapitałowego ${ }^{29}$. Wzmacnia działanie systemu finansowego poprzez wdrażanie nowych technologii. Oferuje swoim klientom szeroką gamę instrumentów służących zarządzaniu ryzykiem ${ }^{30}$. Umożliwia zawieranie transakcji poprzez platformę elektroniczną. CFFEX jest członkiem kilku organizacji międzynarodowych: Światowej Federacji Wymiany (WFE), Międzynarodowej Organizacji Komisji Papierów Wartościowych (IOSCO) oraz Międzynarodowego Stowarzyszenia Swapów i Instrumentów Pochodnych (ISDA) ${ }^{31}$.

W 2010 r. China Financial Futures Exchange stworzyła specjalny program The Postdoctoral Research Station of China Financial Futures Exchange, mający na celu pozyskiwanie wysokiej klasy specjalistów dla chińskiego rynku kapitałowego. Ta platforma naukowa ma stwarzać przyjazne warunki i środowisko badawcze. Program jest prowadzony przy współpracy z renomowanymi instytucjami finansowymi i uczelniami wyższymi.

Instrumentami notowanymi na koniec 2018 r. były kontrakty futures na: CSI 300 Index Futures (IF), CSI 500 Index Futures (IC), SSE 50 Index Futures (IH) oraz kontrakty futures na obligacje pięcioletnie (TF) i dziesięcioletnie (T). W 2018 r. zadebiutowały kontrakty na obligacje dwuletnie (TS), zaś w 2019 r. - opcje na indeks CSI $300^{32}$.

CSI 300 Index Futures (China Securities Index) jest pierwszym powstałym indeksem benchmarkowym na CFFEX. Został opracowany wspólnie z Shanghai

${ }^{28}$ China Financial Futures Exchange, http://www.cffex.com.cn/en_new/jysjs.html (dostęp: 27.01.2020).

29 M. Trombly, A. Dai, China Puts Off Launch of Financial Futures, „Securities Industry News”, 29.01.2007, s. 11.

30 S. Zwick, Asia: Upgraded and primed to trade, „Futures: News, Analysis \& Strategies for Futures, Options \& Derivatives Trades" 2006, no. 12, s. 73.

31 China Financial Futures Exchange, http://www.cffex.com.cn/en_new/GlobalCooperation. html (dostęp: 27.01.2020).

32 China Financial Futures Exchange, http://www.cffex.com.cn/en_new/CSI300IndexFutures (dostęp: 27.01.2020). 
Stock Exchange i Shenzhen Stock Exchange. Pokazuje fluktuacje cenowe i wyniki chińskiego rynku akcji. Jest tworzony w oparciu o bazy danych akcji trzystu największych spółek, które są notowane na giełdach w Szanghaju i Shenzen ${ }^{33}$. Na koniec 2018 r. udział derywatów na analizowany indeks na giełdzie Shanghai Stock Exchange wynosił 72,2\%, zaś na Shenzhen Stock Exchange 27,8\%. Z kolei CSI 500 Index Futures tworzy pięćset kolejnych akcji o największej kapitalizacji. Na koniec 2018 r. udział derywatów na CSI 500 Index Futures na giełdzie Shanghai Stock Exchange wynosił 45,9\%, zaś na Shenzhen Stock Exchange 54,1\%. Kolejnym indeksem jest SSE 50, który obejmuje akcje pięćdziesięciu największych spółek o wysokiej płynności, notowanych na Shanghai Stock Exchange.

Wielkość obrotów oraz wolumen finansowych kontraktów futures i opcji na China Financial Futures Exchange w latach 2016-2019 przedstawiono w tabeli 7. W odróżnieniu od wcześniej omówionych giełd towarowych kryzys lat 2017-2018 spowodował jedynie istotne zmniejszenie dynamiki wzrostu obrotów i wolumenu kontraktów futures. Po zakończeniu kryzysu w 2019 r. zarówno obroty, jak i wolumen bardzo gwałtownie wzrosły - zdecydowanie bardziej niż w przypadku giełd towarowych. W latach 2017-2019 zmiany wolumenu w stosunku do roku poprzedniego wynosiły: 34,14\% (2017), 10,63\% (2018), 144,07\% (2019), a zmiany obrotów: 34,98\% (2017), 6,22\% (2018), 166,52\% (2019). Należy jednak przyznać, że zaobserwowany trend dotyczy kontraktów futures na indeksy akcji: CSI 300 Index Futures (IF), CSI 500 Index Futures (IC), SSE 50 Index Futures (IH). Natomiast kontrakty futures na obligacje pięcioletnie (TF) i dziesięcioletnie (T) w okresie 2016-2019 znajdują się w stagnacji. Również kontrakty futures na obligacje dwuletnie (TS) cieszą się umiarkowanym zainteresowaniem inwestorów. Doprowadziło to do sytuacji, że o ile w latach 2016-2017 kontrakty futures na obligacje dziesięcioletnie (T) były zdecydowanie najbardziej płynnymi instrumentami pochodnymi notowanymi na CFFEX, o tyle na koniec 2019 r. zainteresowanie nimi jest około dwukrotnie mniejsze niż kontraktami CSI 300 Index Futures (IF) lub kontraktami CSI 500 Index Futures (IC) i porównywalne do kontraktów SSE 50 Index Futures (IH). Kontrakty na obligacje dwuletnie (TS) i pięcioletnie (TF) są wykorzystywane przez inwestorów jeszcze rzadziej niż kontrakty T.

33 China Securities Index Company Limited, http://www.csindex.com.cn/en/indices/index-detail/000300 (dostęp: 27.01.2020). 


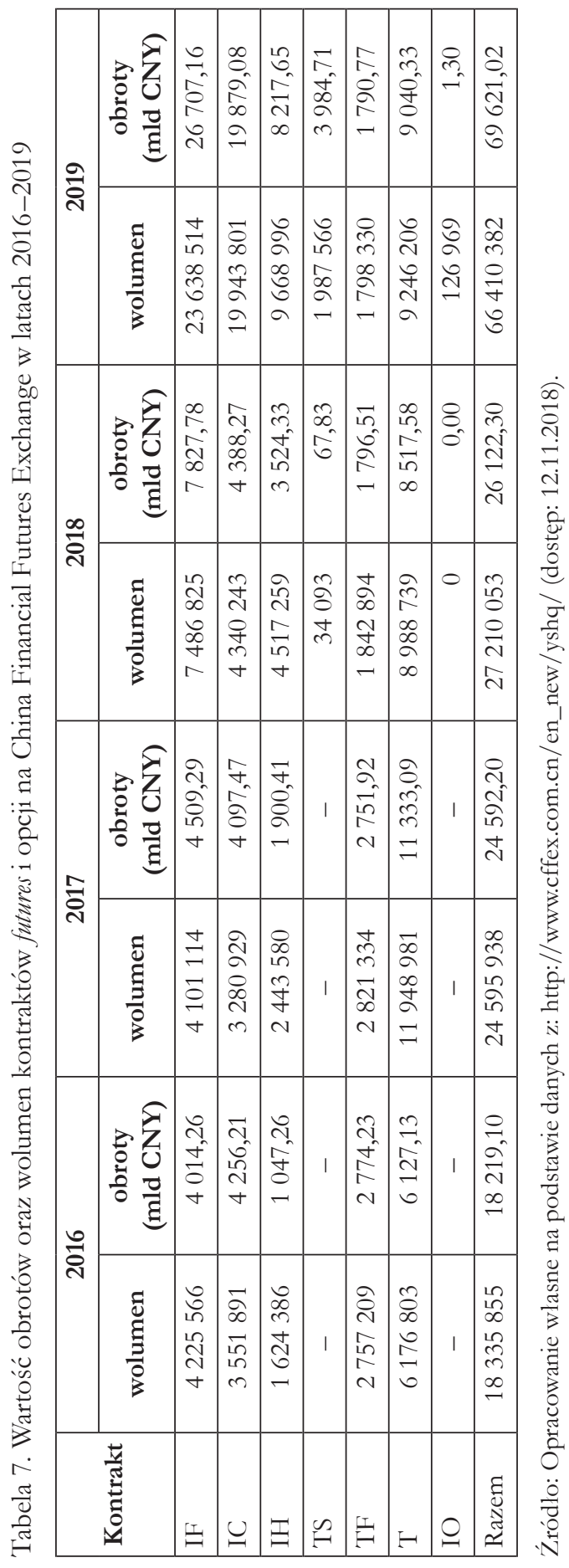




\section{Podsumowanie}

W Chińskiej Republice Ludowej pięć giełd zajmuje się notowaniami pochodnych instrumentów finansowych. Każda z nich znajduje się w grupie światowych liderów w ramach swojej specjalizacji. Jednak wysoką pozycję w rankingach giełd zajęły one dopiero w drugiej dekadzie XXI wieku. Jeszcze przed 2010 r. gama oferowanych instrumentów pochodnych była skromna, zaś zainteresowanie nimi - niewielkie. Po kryzysie finansowym w 2017 r., kiedy obroty i wolumen spadky, w 2019 r. wszystkie giełdy odnotowują bardzo dynamiczny wzrost obrotów i wolumenu.

SSE jest tradycyjna giełda papierów wartościowych, na której notowane są też nieliczne opcje na akcje. Z kolei na CFFEX notowane są kontrakty futures na indeksy akcji (kategoria instrumentów pochodnych rynku kapitałowego) oraz kontrakty futures na obligacje (kategoria procentowych instrumentów pochodnych). Do $2017 \mathrm{r}$. dominująca grupą były kontrakty futures na obligacje, zaś od 2018 r. największym zainteresowaniem cieszą się pochodne indeksowe. Od 2019 r. oferowane są opcje indeksowe, które nie sa jeszcze zbyt popularne.

Powyższe dwie giełdy nie mają w ofercie towarowych instrumentów pochodnych. Walory te sa z kolei jedynymi dostępnymi na trzech pozostałych giełdach: Shanghai Futures Exchange (18 kontraktów futures i 3 kontrakty opcyjne); Dalian Commodity Exchange (19 kontraktów futures i 3 kontrakty opcyjne) i Zhengzhou Commodity Exchange (20 kontraktów futures i 4 kontrakty opcyjne). Na giełdzie Shanghai Futures Exchange towarowe kontrakty futures są oparte wyłącznie na cenach surowców i towarów przemysłowych, na giełdzie Dalian Commodity Exchange do 2014 r. towarowe kontrakty futures oparte były wyłącznie na cenach towarów rolnych, ale od 2015 r. rośnie znaczenie kontraktów futures opartych na cenach towarów metalurgicznych i petrochemicznych. Z kolei na giełdzie Zhengzhou Commodity Exchange do 2006 r. towarowe kontrakty futures oparte były wyłącznie na cenach towarów rolnych, ale od 2007 r. rośnie znaczenie kontraktów futures opartych na cenach petrochemicznych towarów przetworzonych. Na koniec 2019 r. instrumenty te były główną specjalizacją ZCE.

W konkluzji należy stwierdzić, że instrumenty pochodne zyskują coraz większą popularność w Chińskiej Republice Ludowej. Pochodzące z raportów giełdowych dane dotyczące obrotów derywatami wykazują istotny wzrost zainteresowania ze strony inwestorów. Szybko rozwijająca się gospodarka chińska wymaga coraz nowszych metod zabezpieczających, co sprzyja poszerzaniu ofert giełdowych o instrumenty pochodne. Dlatego też poszczególne giełdy osiagaja ponadprzeciętne wzrosty na rynku derywatów zarówno pod względem ilościowym, jak i jakościowym. 


\section{SUMMARY}

\section{DERIVATIVES ON THE STOCK EXCHANGE OF THE PEOPLE'S REPUBLIC OF CHINA}

This paper presents the derivatives market in China. The constantly expanded, wide and standardized range of derivatives offered has increased in attractiveness to both local and foreign investors. Among the range of quoted derivatives on Chinese stock exchanges, we can distinguish financial and commodity products.

Derivatives which are based on stocks and bonds are quoted on the following stockexchange markets: the China Financial Futures Exchange and the Shanghai Stock Exchange.

Derivatives based on commodities are quoted on three stock-exchange markets: the Shanghai Futures Exchange (eighteen futures and three options); the Dalian Commodity Exchange (nineteen futures and three options); and the Zhengzhou Commodity Exchange (twenty futures and four options).

In spite of their complex and complicated form, derivatives are gaining more and more popularity in the PRC. Data from stock-exchange market reports regarding derivatives trading show a strong upward trend and great interest among investors. The rapidly developing Chinese economy requires more and more new hedging methods, which favors the extension of stock-exchange offers with derivatives. The PRC achieves above-average turnover increases in derivatives in terms of quantity. Only the financial crisis in 2017 caused the level of interest in derivatives to decrease. 